\title{
Employers' Feedback on the Competencies of MBA Graduates based on Curriculum and Student Outcomes
}

\author{
Hadge A. Encio, Maribeth G. Buenviaje, Rey Fernan G. Refozar, \\ Jake M. Laguador \\ Business Administration Department, Lyceum of the Philippines University, Batangas City, Philippines
}

\begin{abstract}
This study aims to determine the feedback of the immediate superiors or employers of the Master in Business Administration (MBA) graduates in terms of their competence when considered the curriculum and student outcomes of the MBA program as measuring tool. Descriptive type of research was utilized in the study. Findings revealed that research skill is one of the competencies which obtained the least score on the job performance of the graduates. Employers observed that the MBA graduates utilized appropriate application of technologies in bringing outputs to the customers and other stakeholders as course application of the current trends in Information technology. The graduates were also rated very good in promoting notable behavior in managing the people towards the attainment of vision and mission of the organization with international perspective as application of Human Resource Management and International Business Management.
\end{abstract}

Keywords: business administration, competencies, , curriculum, student outcomes

\section{Introduction}

Employers are considered one of the important customers of the Higher Education Institutions as they provide employment to the graduates. Honing and equipping the students with necessary knowledge, skills and competencies required by the industries [1] [2] [3] are the primary goal of all academic activities of the institution. Advanced graduate study is a continuing professional education that caters to the needs of individuals from industries and academe to further enhance the knowledge and skills suitable for their respective work assignments [4].

The graduate of MBA program shall be competent and successful business leaders, managers, industry and academe practitioners who possess the required professional skills in leadership and management of business enterprises and organizations and who can apply the universal humanistic values and contribute to the growth and development of their community. MBA graduates shall be responsible professionals who can apply research skills as well as quantitative analysis or other problem solving techniques in their work environment as employees, business partners or entrepreneurs.

Determining the level of competencies of business graduates provides how the graduate program of the institution delivered its outcomes effectively through evaluating the performance of the graduates. Employers' feedback [5] provides substantial information to the higher educational institution on how to continuously improve its academic services and employers are considered the best judge of quality of the graduates. Baruch, Bell and Gray [6] noted that the most prominent impact of competencies and skills portfolio gained was on both internal and external measures of career success. The job assignments, duties and responsibilities should be carried out with accuracy and reliability. Business operation of every organization requires competent employees to sustain the competitive edge in the local and global market. Job activities are changing and getting more complex, new competencies are being required [7].

As part of the outcomes-based education implementation [8], [9], [10] HEIs are guided with certain concepts and principles that will measure the performance of the learners. Student Outcomes of the MBA program along with the curriculum gives clear direction on what to achieve at the end of the degree program. Responses of the employers serve as substantial input in reviewing the curriculum and the student development program to achieve the desired outcomes of the program.

This study aims to determine the level of competency as evaluated by their employers based on curriculum and student outcomes of MBA program; and to test the relationship of employers' feedback between curriculum and student outcomes. The result of the study also provides action plan to the implementation of curriculum and delivery of instruction.

\section{Methods}

The study used a descriptive type of research method. In descriptive-survey method research, participants answered the questions administered through questionnaires. This study focuses on the 71 individual employers of MBA graduates from 2013 to 2015. Total population of the employers served as the 
actual respondents. Out of 71 total populations only 45 or 63.4 percent of them responded to the questionnaire sent through email and social media using Google Forms as online platform. The instrument used for employers' feedback was taken from the curriculum of the degree program and the identified student outcomes. This was content-validated by two experts in Business Administration and one expert in educational management. The resulting Cronbach alpha is 0.86 which implies that the instrument is valid and good to be utilized in the study.

The names and email addresses of the employers were also obtained from the MBA graduates. The respondents were informed regarding the purpose of the study. The data gathered were treated with strict confidentiality and solely used for the purpose of this study. Questionnaires for the graduates and employers were sent to them through Facebook and Electronic Mail from February 25 to April 30, 2016.

Weighted mean was used to describe the evaluation of the employers while Pearson-product moment correlation coefficient was utilized to test the relationship in the competency evaluation between the curriculum and student outcomes.

The given scale was used to interpret the result of the study: $3.51-4.00$ : Very Good (VG); $2.51-3.50$ : Good (G); 1.51 - 2.50: Fair (F); 1.00 - 1.50: Poor (P).

\section{Results and Discussion}

Table 1 reveals the employers' assessment on the competencies of the MBA Graduates based on curriculum. Employers also assessed the competencies of the MBA Graduates based on the content of the curriculum which is considered the heart of any educational program [11].

Table 1. Employers' Assessment of Competencies of the MBA Graduates based on Curriculum

\begin{tabular}{|c|c|c|c|}
\hline Competencies & WM & VI & Rank \\
\hline $\begin{array}{l}\text { 1. Provide ideas or opinion during quality planning /meeting of the department } \\
\text { related to future directions of the products/services offered by the organization } \\
\text { (MANAGERIAL ECONOMICS/MARKETING MANAGEMENT/QUALITY } \\
\text { PLANNING and ANALYSIS) }\end{array}$ & 3.39 & $\mathrm{G}$ & 4 \\
\hline $\begin{array}{l}\text { 2. Promotes notable behavior in managing the people towards the attainment of } \\
\text { vision and mission of the organization with international perspective (HUMAN } \\
\text { RESOURCE MANAGEMENT/INTERNATIONAL BUSINESS } \\
\text { MANAGEMENT) }\end{array}$ & 3.51 & VG & 2 \\
\hline $\begin{array}{l}\text { 3. Participates in making decisions and managing the operations of the department } \\
\text { focusing on strategic issues covering quality and process management } \\
\text { (QUALITY/OPERATIONS MANAGEMENT) }\end{array}$ & 3.22 & $\mathrm{G}$ & 7 \\
\hline $\begin{array}{l}\text { 4. Conducts research related to business administration for continuous improvement } \\
\text { of the organization (RESEARCH) }\end{array}$ & 2.36 & $\mathrm{~F}$ & 10 \\
\hline $\begin{array}{l}\text { 5. Applies some basic statistical tools in everyday business operation in the } \\
\text { department (STATISTICS) }\end{array}$ & 2.84 & $\mathrm{G}$ & 9 \\
\hline $\begin{array}{l}\text { 6. Demonstrates the ability to analyze some legal terms and principles of } \\
\text { commercial rules and regulations (BUSINESS LAW) }\end{array}$ & 3.08 & $\mathrm{G}$ & 8 \\
\hline $\begin{array}{l}\text { 7. Builds mechanisms for creating new ventures for the organization that affect } \\
\text { economic development (ENTREPRENEURSHIP) }\end{array}$ & 3.27 & G & 6 \\
\hline $\begin{array}{l}\text { 8. Supports the organization in appraising the firm's financial standing and } \\
\text { competence (FINANCIAL MANAGEMENT) }\end{array}$ & 3.34 & $\mathrm{G}$ & 5 \\
\hline $\begin{array}{l}\text { 9. Utilizes appropriate application of technologies in bringing outputs to the } \\
\text { customers and other stakeholders. (CURRENT TRENDS IN IT) }\end{array}$ & 3.59 & VG & 1 \\
\hline $\begin{array}{l}\text { 10. Participates in the strategic planning of the department in the preparation and } \\
\text { implementation of operational plans, budgets and controls (COST } \\
\text { MANAGEMENT) }\end{array}$ & 3.46 & G & 3 \\
\hline Composite Me & 3.21 & $\mathbf{G}$ & \\
\hline
\end{tabular}

The MBA graduates obtained a very good performance rating in terms of the application of the current trends in information technology through utilizing appropriate application of technologies in bringing outputs to the customers and other stakeholders (4.59) and in promoting notable behavior in managing the people towards the attainment of vision and mission of the organization with international perspective (3.51) as the application of Human Resource Management and International Business Management.

The immediate superiors acknowledged the competence of the MBA graduates in terms of utilizing the application of various technologies available in the company which are essential in running the business smoothly leading towards a paramount customer satisfaction. Maximizing the use of social media is one way of putting the business visible in all ages and in all walks of life. Getting connected to people is now easy and 
disseminating information about the product is now cheaper because of the power of the available social networking and blogging sites.

They were also given good performance rating in terms of their participation in the strategic planning of the department in the preparation and implementation of operational plans, budgets and controls (3.46) as the application of cost management; providing ideas or opinion during quality planning /meeting of the department related to future directions of the products/services offered by the organization (3.39) as application of Managerial Economics/Marketing Management/Quality Planning and Analysis; and supporting the organization in appraising the firm's financial standing and competence (3.34) as application of Financial Management is concerned.

MBA Graduates were given responsibilities to participate in the strategic planning of their respective departments wherein their immediate superiors valued their opinion about the preparation for future plans of the company. Organizations practice democratic approach to management in order to solicit ideas and information on how to face some financial challenges of the business sector on the next few years.

The performance of the graduates in building mechanisms for creating new ventures for the organization that affect economic development (3.27) was also rated by the employers as good in the application of the Entrepreneurship course and in participating in making decisions and managing the operations of the department focusing on strategic issues covering quality and process management (3.22) as application of Quality/Operations Management. This signifies that MBA graduates were able to contribute in the realization of the company's mission through identifying areas for continuous improvement and measuring the accomplishment of various strategies as part of their quality management plan.

Demonstrating the ability to analyze some legal terms and principles of commercial rules and regulations (3.08) as application of Business Law and applying some basic statistical tools in everyday business operation in the department as application of Statistics also obtained the lowest mean score among the indicators with good performance rating. However, the MBA graduates were rated with fair performance rating in conducting research related to business administration or continuous improvement of the organization (2.36) as application of Research course in the MBA programs with the least weighted mean score.

Research skill is identified competence with the least utilization among the MBA graduates. They were not able to contribute so much in the research capacity of the organization. Their ability to identify problems and issues in the company might not be supported with scientific basis which can be derived from conducting research. They might assist the department in searching for necessary information needed by the company operation but solving specific issues through observation and interviews that will be used to support their hypothesis or assumption are the lacking set of evidence.

The composite mean score of 3.21 implies that the MBA graduates obtained a good performance rating from their respective employers as application of the MBA curriculum to their present job. As Jackson [12] mentioned that "it is important to note that perhaps only a small portion of an industry-relevant competency profile may be nurtured in a higher education environment and applied successfully in the workplace" (p.85).

Table 2. Employers' Feedback on Competencies of the MBA Graduates based on Student Outcomes

\begin{tabular}{|cl|c|c|c|}
\hline \multicolumn{2}{|c|}{ Student Outcomes } & WM & VI & Rank \\
\hline 1. & Communicates effectively both oral and written in dealing with customers & 3.57 & VG & 2 \\
\hline 2. & Thinks critically and makes decisions to business case studies & 3.28 & $\mathrm{G}$ & 3 \\
\hline 3. & $\begin{array}{l}\text { Integrates a variety of approaches and practices from various disciplines to analyze and } \\
\text { evaluate organizational situation }\end{array}$ & 3.13 & $\mathrm{G}$ & 5 \\
\hline 4. & Diagnoses accurately the competitive performances of both local and international enterprises & 3.09 & $\mathrm{G}$ & 6 \\
\hline 5. & Applies knowledge necessary to ethically manage today's business operations & 3.62 & $\mathrm{G}$ & 1 \\
\hline 6. & Leads community - based activities for sustainable development Composite Mean & 3.18 & $\mathrm{G}$ & 4 \\
\hline & $\mathbf{3 . 3 1}$ & $\mathbf{G}$ & \\
\hline
\end{tabular}

Table 2 presents the employers' feedback on the competencies of the MBA Graduates based on Student Outcomes. The set of student outcomes for MBA program serves as a measure to determine whether the students really acquired specific knowledge and skills after completing certain course or subject. The present study tried to evaluate if these student outcomes were being applied by the students through asking their immediate superior.

Employers assessed the competencies of the MBA Graduates based on the student outcomes of the degree program. Competency profiling traditionally involves the deterministic process of devising a framework of abilities, skills, traits, values and knowledge which directly enhances individual performance in the workplace [12]. The MBA graduates obtained a very good performance rating in terms of applying knowledge necessary to ethically manage today's business operations (3.62) and communicating effectively both oral and written in dealing with customers (3.57).

MBA graduates obtained good performance rating as manifestation of student outcomes to their present job through thinking critically and making decisions to business case studies (3.28) and leading community - 
based activities for sustainable development (3.18). Meanwhile, integrating a variety of approaches and practices from various disciplines to analyze and evaluate organizational situation (3.13) and diagnosing accurately the competitive performances of both local and international enterprises (3.09) obtained the least weighted mean scores with good verbal interpretation. The University also provides experience to the students on how to serve the community through various extension projects and outreach programs as part of their student outcomes [13], [14], [15]. It is necessary for them to embrace the sense of volunteerism that could let them express their generosity to the needy.

The composite mean score of 3.31 implies that the MBA graduates really possessed the student outcomes set for the MBA degree program as demonstrated in their respective work assignments based on the observations of their immediate superiors.

Table 3. Relationship in the Employers' Feedback Between Curriculum and Student Outcomes

\begin{tabular}{|l|l|l|l|}
\hline & r-value & p-value & Remarks \\
\hline Feedback in terms of Curriculum and Student Outcomes & $\mathbf{. 4 8 0}(* *)$ & $\mathbf{. 0 0 0}$ & Highly Significant \\
\hline
\end{tabular}

Table 3 reveals the relationship in the employers' feedback between curriculum and student outcomes. There is a significant relationship in the employer's feedback on the competencies of MBA graduates between curriculum and student outcomes as denoted by the computed p-value which is less than 0.01 level of significance. This signifies that the higher the evaluation of the employers in the competencies of the graduates in terms of the application of curriculum in the workplace, there is also high feedback on the demonstration of student outcomes. The impact of the MBA program to job performance could be considered as factor or basis to describe the competency evaluation as perceived by the employers. This can also be affected by the subjective manner of evaluation due to individual differences and characteristics of the employers who evaluated the graduates. There are some aspects on the impact of MBA program to performance that could be considered low by the graduates because they already possessed certain knowledge or skills on a particular subject/course taken in the program. Lubis [16] stressed that the business graduates were technically capable of handling jobs assigned to them and their skills acquired from the school help them to be productive in their present positions.

\section{Proposed Action Plan}

The proposed action plan aimed to enhance the implementation of curriculum and student outcomes which serves as guide of the institution in measuring specific performance or results of the employed strategies. In terms of competencies, conducting research is the least evident capacity of the graduates being utilized in the organization. Meanwhile, diagnosing accurately the competitive performances of both local and international enterprises needs to be strengthened in the list of student outcomes.

Table 4. Action Plan Towards the Implementation of the Curriculum and Student Outcomes

\begin{tabular}{|c|c|c|}
\hline Key Result Area & Strategies & Persons Involved \\
\hline $\begin{array}{l}\text { Curriculum: } \\
\text { Research and } \\
\text { Statistics }\end{array}$ & $\begin{array}{l}\text { - Conduct simple action research based on the identified company issues } \\
\text { or problems where the students are currently connected as part of the } \\
\text { course requirement in } \\
\text { Give activities that will apply knowledge of statistics on forecasting as } \\
\text { requirement in Operations Management } \\
\text { Provide an avenue for the students to present the results of their study } \\
\text { with an audience from undergraduate business program }\end{array}$ & $\begin{array}{l}\text { Professor in OM, students } \\
\text { enrolled in OM }\end{array}$ \\
\hline Student Outcomes & $\begin{array}{l}\text { Provide business case studies for the students to analyze comparing the } \\
\text { performance of local and international enterprises as part of the course } \\
\text { requirement in International Business Management } \\
\text { Provide community extension projects to the adapted community in } \\
\text { SHL Restoration Village as part of their requirements in managerial } \\
\text { economics } \\
\text { Include the students in benchmarking visits or plant tour to let them } \\
\text { observe the best practices of business organization that could be of help } \\
\text { to their present work assignments }\end{array}$ & $\begin{array}{l}\text { Professor in International } \\
\text { Business Management, } \\
\text { Industry Partners, } \\
\text { Students enrolled in the } \\
\text { course, Community } \\
\text { Extension Personnel }\end{array}$ \\
\hline
\end{tabular}

\section{Conclusion and Recommendation}

The employers rated the graduates with High performance in terms of their competence using the curriculum They gave the MBA graduates better opportunities and greater responsibilities to handle management roles in the organization and participate in the decision making process. Employers also believed in the high performance of the MBA graduates when student outcomes of the MBA program was used the measuring tool.

Employers of the presently enrolled graduate school students may also be asked about the skills needed by their employees through Training Needs Analysis Survey so that the academic institution could align the

\begin{tabular}{|c|c|}
\hline DOI: $10.9790 / 487 \mathrm{X}-180804101105$ & Www.iosriournals.org \\
\hline
\end{tabular}


course design based on the specific needs of the organizations to improve the performance of their human resources towards greater productivity. Employers can also serve as the Board of Advisers to make the curriculum [17] of the graduate degree program offerings updated to ensure its relevance to actual work assignments.

\section{References}

[1] J. M. Laguador and L. R. Ramos, Industry-partners' preferences for graduates: Input on curriculum development. Journal of Education and Literature, 1(1), 2014, 1-8.

[2] C. I. Dotong, School-Related Factors in the Development of Graduates' Competencies towards Employability. Journal of Education and Literature, 2(1), 2014, 28-36.

[3] L. P. Macatangay, Tracer Study of BSCS Graduates of Lyceum of The Philippines University from 2004-2009. Academic Research International, 4(5), 2013, 361

[4] M. G. Buenviaje, H. A. Encio, R. F. G. Refozar, A. Anuran, N. C. Camello, J. M. Laguador, Employability and Skills of MBA Graduates from Literature Review as Input to Student Development Program, Journal of Research in Business and Management, 4(5), 2016, 16-21.

[5] A. B. Aquino, C. O. Del Mundo and G. R. Quizon, Employers' Feedbacks on the Performance of Teacher Education Graduates. Asia Pacific Journal of Multidisciplinary Research, 3(4), 2015.

[6] Y. Baruch, M. P. Bell and D. Gray, Generalist and specialist graduate business degrees: Tangible and intangible value. Journal of Vocational Behavior, 67(1), 2005, 51-68.

[7] V. Bortkevičienè, Entrepreneurial Competences Implications For Employability: Expression And Importance. Applied Research in Health \& Social Sciences: Interface \& Interaction/Sveikatos ir Socialiniu Mokslu Taikomieji Tyrimai: Sandura ir Saveika, 11(1), 2014

[8] L. D. Borsoto, J. D. Lescano, N. I. Maquimot, M. J. N. Santorce, A. F. Simbulan and A. M. Pagcaliwagan, Status Of Implementation And Usefulness Of Outcomes-Based Education In The Engineering Department Of An Asian University. Asian Journal of Management Science and Economics, 1(1), 2014.

[9] J. M. Laguador and C. I. Dotong, Knowledge versus Practice on the Outcomes-Based Education Implementation of the Engineering Faculty Members in LPU. International Journal of Academic Research in Progressive Education and Development, 3(1), 2014, 6374.

[10] I. L. An, Impact of Outcome-Based Education Instruction to Accountancy Students in an Asian University. Asia Pacific Journal of Education, Arts and Sciences, 1(5), 2014, 48-52.

[11] S. Natarajan and K. B. Kumar, Employability of MBA students with HR Specialization: The Case Study of Educational Institution in India. International Journal of Advances in Management and Economics, 3 (6), 2014, 01-07.

[12] D. Jackson, Profiling industry-relevant management graduate competencies: The need for a fresh approach. International Journal of Management Education, 8(1), 2009, 85-98.

[13] J. A. M. A. Rubio, C. V. P. Pentinio, J. C. Ascan, M. C. D. Mendoza, J. V. Vito and H. A. Encio, Involvement in Community Extension Program of Business Administration Students in one Higher Education Institution in the Philippines. Asia Pacific Journal of Multidisciplinary Research, 4(1), 2016.

[14] J. M. Laguador and N. H. Chavez, Assessment Of Engineering Students' acquired Affective Learning From Involvement In Community Extension Services. Academic Research International, 4(3), 2013, 188.

[15] J. M. Laguador, L. B. Mandigma and E. Agena, Community Extension Service In The Waste Management Practices Of Brgy. Wawa Residents In Batangas City. Academic Research International, 4(4), 2013. 141.

[16] D. O. Lubis, Success Factors of Business Graduates of Lyceum of the Philippines University: Its Implications to Curriculum Functionality. IAMURE International Journal of Business and Management, 1(1), 2012, 42.

[17] N. H. Chavez, C. I. Dotong, N. C. Camello and J. M. Laguador, Employability of Engineering Graduates of one Asian University as Basis for Curriculum Review, International Journal of Science and Engineering, 1 (6), 2016. 